\title{
PENGARUH INTEGRITAS, PENGETAHUAN DAN PEMAHAMAN PERPAJAKAN TERHADAP KEPATUHAN WAJIP PAJAK
}

\author{
Nurul Khotimah'1), Hisnol Jamali2), Asbi Amin³) \\ Nurulkhotimah23397@gmail.com
}

1) Mahasiswa Program Studi Akuntansi pada Sekolah Tinggi Ilmu Ekonomi Bongaya Makassar

2,3) Dosen Program Studi Akuntansi pada Sekolah Tinggi Ilmu Ekonomi Bongaya Makassar

\begin{abstract}
ABSTRAK
Penelitian ini bertujuan untuk mengetahui pengaruh Integritas, Pengetahuan dan Pemahaman Perpajakan terhadap Kepatuhan Wajib Pajak Pada Kantor Pelayanan Pajak Pratama (KPP) Makassar Utara. Pengumpulan data menggunakan data primer yang diperoleh dari kuesioner dengan menggunakan tekhnik sampel jenuh. Populasinya sebanyak 45 Account Representative (AR) pajak di Kantor Pelayanan Pajak (KPP) Pratama Makassar Utara dan sampelnya sebanyak 45 Account Representative (AR). Hasil kuesioner tersebut telah diuji validitas dan reliabilitasnya, juga telah diuji asumsi klasik berupa Normalitas, Multikolinearitas, Heteroskedastisitasnya. Metode Analisis data menggunakan tekhnik analisis dekstiptif dan Regresi Berganda. Hasil penelitian ini menunjukkan bahwa integritas tidak berpengaruh terhadap kepatuhan wajib pajak, pengetahuan dan pemahaman perpajakan berpengaruh positif dan signifikan terhadap kepatuhan wajib pajak.
\end{abstract}

Kata kunci : Integritas, pengetahuan dan pemahaman, kepatuhan wajib pajak

\begin{abstract}
This study aims to determine the effect of Integrity, Knowledge and Tax Understanding of Taxpayer Compliance At Tax Office Pratama (KPP) Makassar North. Data collection uses primary data obtained from questionnaires using saturated sample techniques. The population is 45 Account Representative (AR) tax in Tax Office (KPP) Pratama Makassar Utara and the sample is 45 Account Representative (AR). The results of the questionnaire have been tested for validity and reliability, also has tested the classical assumptions of Normality, Multicolinearity, Heteroskedastisitasnya. Methods Data analysis uses decstiptive and multiple regression analysis techniques.The results of this study indicate that integrity does not affect taxpayer compliance, knowledge and understanding of taxation have a positive and significant impact on taxpayer compliance.
\end{abstract}

Keywords: Integrity, knowledge and understanding, taxpayer compliance 
Issue 1 (Agustus, 2018)

\section{Latar Belakang}

Sumber penerimaan negara dapat dibagi menjadi dua sumber utama yaitu sumber penerimaan dari dalam negeri dan pinjaman dari luar negeri. Sumber penerimaan negara yang berasal dari dalam negeri dapat dibedakan menjadi tiga yaitu penerimaan negara bukan pajak (PNBP), penerimaan pajak, dan hibah. Salah satu sumber penerimaan yang diandalkan pemerintah dalam membiayai kepentingan pembangunan serta pengeluaran pemerintah adalah dari sektor penerimaan perpajakan. Peningkatan penerimaan di sektor pajak melalui Direktorat Jendral Pajak, pemerintah terus melaksanakan terobosan guna mengoptimalkan penerimaan di sektor ini melalui kebijakankebijakan yang dikeluarkan. Salah satu langkah yang diambil oleh Direktorat Jendral Pajak melakukan reformasi di bidang perpajakan (Tax Reform), dimana dalam reformasi perpajakan tahun 1983, sistem pemungutan pajak telah mengalami perubahan yang cukup signifikan yaitu perubahan dari official assessmen sytstem menjadi self assessment system.

Sistem self assessment lebih membutuhkan kesadaran wajib pajak untuk dengan patuh melaksanakan kewajiban perpajakan. Dengan semakin tinggi kesadaran wajib pajak untuk tepat waktu menyetor pajak, maka diharapkan semakin besar penerimaan pajak negara. Bila ingin memaksimalkan penerimaan pajak dengan sistem self assessment, selain berusaha meningkatkan jumlah wajib pajak aktif, maka pemerintah juga harus berupaya agar wajib pajak semakin sadar bahwa peranan membayar pajak sangatlah penting bagi tercapainya pembangunan nasional (Herryanto.,2013). Namun faktanya dengan hadirnya sistem self assessment belum juga memberikan solusi terbaik. Pada tahun 2016 Mentri Keuangan mengungkapkan bahwa penerimaan pajak dari Wajib Pajak Orang Pribadi untuk tahun 2015 secara nominal masih terlalu rendah.

Fenomena yang terjadi pada Kantor Pelayanan Pajak pratama Makassar Utara, diperoleh data perkembangan tingkat kepatuhan Wajib Pajak selama 3 (tiga) tahun yang dapat dilihat pada tabel 1.1 berikut ini.

Tabel 1. Tingkat Kepatuhan WPOP Pada KPP Pratama Makassar Utara

\begin{tabular}{|c|c|c|c|}
\hline $\begin{array}{c}\text { Tahun } \\
\text { Pajak }\end{array}$ & $\begin{array}{c}\text { Jumlah WP OP Terdaftar } \\
\text { Wajib SPT Tahunan }\end{array}$ & $\begin{array}{c}\text { Jumlah WP OP } \\
\text { Patuh }\end{array}$ & $\begin{array}{c}\text { Jumlah WP OP } \\
\text { Tidak Patuh }\end{array}$ \\
\hline 2014 & 70.219 & 51.579 & 18.640 \\
\hline 2015 & 72.735 & 36.324 & 36.411 \\
\hline 2016 & 77.942 & 41.217 & 36.725 \\
\hline
\end{tabular}

Sumber : Seksi PDI KPP Pratama Makassar Utara (2018)

Tabel 1.1 menunjukkan jumlah WP OP terdaftar SPT Tahunan Pajak Penghasilan setiap tahunnya mengalami peningkatan. Hal ini dilihat pada tahun 2014 sebanyak 70.219 wajib pajak, tahun 2015 naik menjadi 72,735 wajib pajak, tahun 2016 naik menjadi 77.942 wajib pajak. Jumlah wajib pajak orang pribadi terdaftar wajib spt tahunan pajak penghasilan pada tahun 2014 ke tahun 2015 mengalami peningkatan sebanyak 2.516 wajib pajak atau $3,59 \%$ dari jumlah wajib pajak orang pribadi terdaftar wajib spt tahunan pajak penghasilan tahun 2014, pada tahun 2015 ke tahun 2016 mengalami

Halaman 2

Authors : Nurul Khotimah dkk. (Agustus 2018). $01-15$ 
peningkatan sebanyak 5.207 wajib pajak atau 7,16\% dari jumlah wajib pajak orang pribadi terdaftar wajib spt tahunan pajak penghasilan tahun 2015.

Wajib pajak orang pribadi yang melaporkan SPT tahunan pajak penghasilan tepat waktu tahun pajak 2014 ke tahun 2015 mengalami penurunan sebesar 15.255 wajib pajak orang pribadi atau 29,58\% dari 51.579 wajib pajak orang pribadi tahun pajak 2014, sedangkan pada tahun pajak 2015 ke tahun pajak 2016 mengalami peningkatan sebesar 4.893 wajib pajak orang pribadi atau $13,48 \%$ dari 36.324 wajib pajak orang pribadi tahun pajak 2015. sedangkan tingkat kepatuhan wajib pajak orang pribadi dalam pelaporan spt tahunan pajak penghasilan di kantor pelayanan pajak pratama makassar utara setiap tahunnya belum terealisasi dengan baik.

Fenomena tersebut menggambarkan bahwa jumlah wajib pajak orang pribadi yang patuh setiap tahun masih belum optimal. Kepatuhan wajib pajak menjadi sangat penting karena apabila wajib pajak tidak patuh terhadap peraturan perpajakan, maka secara tidak langsung akan menumbuhkan upaya penghindaran wajib pajak yang menyebabkan berkurangnya penerimaan pajak negara maupun daerah. Pemerintah perlu menumbuhkan rasa kesadaran dan kepatuhan wajib pajak secara terus menerus untuk mencapai target pajak yang telah ditetapkan. (Chau.,2013) mengatakan bahwa kepatuhan wajib pajak merupakan faktor terpenting yang perlu dikaji secara intensif oleh pemerintah untuk meningkatkan penerimaan tiap tahunnya. Upaya penegakan yang kuat memiliki dampak positif atas kepatuhan perpajakan secara keseluruhan (Ho.,2011). Tinggi rendahnya kepatuhan wajib pajak dipengaruhi oleh beberapa faktor, diantaranya yaitu Integritas, pengetahuan dan pemahaman perpajakan.

Wajib pajak dalam melakukan peraturan perpajakannya harus menggunakan integritas. Integritas masing-masing wajib pajak dalam melaksanakan peraturan perpajakan dapat mempengaruhi kepatuhan wajib pajak itu sendiri. Integritas didefinisikan sebagai suatu elemen karakter yang melandasi timbulnya pengakuan professional. Integritas wajib pajak meliputi sikap berani, jujur, dan bertanggung jawab dalam menaati segala peraturan undang-undang perpajakan yang berlaku. (Insadha.,2012) menyatakan bahwa integritas merupakan sikap yang dapat menerima kesalahan yang tidak disengaja dan perbedaan pendapat yang jujur, tetapi tidak dapat menerima kecurangan prinsip.

Pengetahuan dan pemahaman peraturan perpajakan adalah proses dimana wajib pajak mengetahui tentang perpajakan dan mengaplikasikan pengetahuan itu untuk membayar pajak. Pengetahuan dan pemahaman peraturan perpajakan yang dimaksud mengerti dan paham tentang ketentuan umum dan tata cara perpajakan (KUP) yang meliputi tentang bagaimana cara menyampaikan Surat Pemberitahuan (SPT), pembayaran, tempat pembayaran, denda dan batas waktu pembayaran atau pelaporan SPT. Kesadaran masyarakat untuk membayar pajak terutama tergantung pada pengetahuan dan pemahaman masyarakat mengenai aturan perpajakan dan tingkat pendidikan (Qomaria.,2013).

Penelitian ini merupakan pengembangan penelitian yang dilakukan oleh (Wisnu.,2016) belum menunjukkan bahwa integritas pajak berpengaruh positif signifikan terhadap kepatuhan wajib pajak, dan (Setiawan.,2017)

Halaman 3

Authors : Nurul Khotimah dkk. (Agustus 2018). $01-15$ 
tentang "pengaruh kesadaran, pengetahuan dan pemahaman perpajakan terhadap kepatuhan wajib pajak" dengan hasil penelitian terdapat pengaruh yang signifikan antara pengetahuan dan pemahaman perpajakan terhadap tingkat kepatuhan wajib pajak. Dari sejumlah penelitian yang membahas pengaruh pengetahuan dan pemahaman perpajakan masih kurang yang mengkaitkannya dengan integritas wajib pajak.

Berdasarkan fenomena dan hasil penelitian terdahulu penulis tertarik untuk melakukan penelitian mengenai integritas, pengetahuan dan pemahaman perpajakan terhadap kepatuhan wajib pajak yang dilakukan di Kantor Pelayanan Pajak Pratama Makassar Utara, dengan judul "Pengaruh Integritas, Pengetahuan dan Pemahaman Perpajakan Terhadap Kepatuhan Wajib Pajak Pada Kantor Pelayanan Pajak (KPP) Pratama Makassar Utara"

\section{Tinjauan Teoritis}

\section{Kepatuhan Wajib Pajak}

Penelitian (Rustiyaningsih.,2011) kepatuhan perpajakan diartikan sebagai suatu keadaan yang mana wajib pajak patuh dan mempunyai kesadaran dalam memenuhi kewajiban perpajakan. Kepatuhan yang dimaksud meliputi: (a) Kepatuhan formal yaitu suatu keadaan dimana wajib pajak memenuhi kewajiban secara formal sesuai dengan ketentuan dalam Undang-Undang Perpajakan. Kepatuhan formal merefleksikan pemenuhan kewajiban penyetoran dan pelaporan pajak sesuai dengan jadwal yang telah ditentukan, dan (b) Kepatuhan materiil, kepatuhan materiil lebih menekankan pada aspek substansinya yaitu jumlah pembayaran pajak telah sesuai dengan ketentuan. Dalam arti perhitungan dan penyetoran pajak telah benar.

\section{Integritas}

Integritas didefinisikan sebagai suatu elemen karakter yang melandasi timbulnya pengakuan professional. Integritas wajib pajak meliputi sikap berani, jujur, dan bertanggung jawab dalam menaati segala peraturan undang-undang perpajakan yang berlaku. Menurut (Insadha.,2012) terdapat beberapa indikator Integritas Wajib Pajak dalam mentaati peraturan UndangUndang No 16 Tahun 2009, meliputi: (1) berani, berani erat kaitannya dengan memulai, Wajib Pajak harus memiliki keberanian dalam memulai untuk membayar pajaknya. (2) jujur, wajib pajak harus jujur melaporkan seluruh harta kekayaan yang belum dicantumkan pada surat pernyataan harta ( $\mathrm{SPH}$ ) maupun surat pemberitahuan tahunan (SPT), dan (3) bertanggung jawab, bertanggung Jawab atas kewajiban membayar pajak sebagai cerminan kewajiban kenegaraan di bidang perpajakan berada pada anggota masyarakat sendiri untuk memenuhi kewajiban pajaknya.

\section{Pengetahuan dan pemahaman wajib pajak}

Pengetahuan dan Pemahaman akan peraturan perpajakan adala proses dimana wajib pajak mengetahui tentang perpajakan dan mengaplikasikan pengetahuan itu untuk membayar pajak. Menurut

Halaman 4

Authors : Nurul Khotimah dkk. (Agustus 2018). $01-15$ 
(Rahayu.,2010) terdapat beberapa indikator wajib pajak dalam mengetahui dan memahami peraturan perpajakan, yaitu: (1) Pengetahuan dan Pemahaman mengenai ketentuan umum dan tata cara perpajakan, ketentuan Umum dan Tata Cara Perpajakan sudah diatur dalam Undang-Undang Republik Indonesia Nomor 6 tahun 1983 yang kemudian mengalami beberapa perubahan atau penyempurnaan yang menghasilkan Undang-Undang Nomor 16 tahun 2009 tentang Penetapan Peraturan Pemerintah Pengganti UndangUndang Nomor 5 Tahun 2008 Tentang Perubahan Keempat Atas UndangUndang Nomor 6 Tahun 1983 Tentang Ketentuan Umum dan Tata Cara Perpajakan Menjadi Undang-Undang. Isi dari ketentuan umum dan tata cara perpajakan tersebut antara lain mengenai hak dan kewajiban wajib pajak, Surat Pemberitahuan (SPT), Nomor Pokok Wajib Pajak (NPWP), tata cara pembayaran pajak, dan pemungutan serta pelaporan pajak. (2) Pengetahuan dan Pemahaman mengenai sistem perpajakan di Indonesia, Indonesia menganut sistem self assessment dalam pemungutan pajaknya. Artinya, wajib pajak diberikan keleluasaan untuk mendaftarkan diri, menghitung, membayar dan melaporkan pajaknya. Menurut (Resmi.,2013) self assessment system adalah sistem pemungutan pajak yang memberikan wewenang penuh kepada wajib pajak untuk menentukan sendiri jumlah pajak yang terutang setiap tahunnya sesuai dengan peraturan perundang-undangan perpajakan yang berlaku. Sistem ini inisiatif sepenuhnya berada ditangan wajib pajak untuk menghitung dan memungut serta melaporkan jumlah harta kekayaan dan pajak terutang ke Kantor Pelayanan Pajak (KPP) dan menyetorkan pembayaran sendiri pajaknya ke Kantor Kas Negara. Tujuan utama melalui adanya sistem self assessment adalah kepatuhan sukarela dari wajib pajak untuk jujur melaporkan usahanya dan (3) Pengetahuan dan pemahaman mengenai fungsi perpajakan. Pada dasarnya pajak memiliki fungsi sebagai sumber keuangan Negara. Namun terlepas dari itu, pajak juga memiliki fungsi lain yang tidak kalah pentingnya yaitu pajak sebagai fungsi pengatur. Berikut akan dijelaskan mengenai masing-masing fungsi pajak tersebut, (Resmi., 2017).

\section{Metode Penelitian}

Penelitian ini menggunakan pendekatan penelitian kuantitatif dan juga menggunakan jenis penelitian deskriptif. Pendekatan kuantitatif adalah metode yang digunakan untuk meneliti pada populasi atau sampel tertentu, pengumpulan data menggunakan instrument penelitian, analisis data yang bertujuan untuk menguji hipotesis yang telah ditetapkan, (Sugiyono.,2014). Penelitian kuantitatif dengan format deskriptif bertujuan untuk menjelaskan, meringkaskan berbagai kondisi, berbagai situasi, atau berbagai variabel yang timbul di masyarakat yang menjadi objek penelitian berdasarkan apa yang terjadi. Jumlah sampel yang digunakan dalam penelitian ini adalah sebanyak 45 WP OP. 
Issue 1 (Agustus, 2018)

\section{Hasil Penelitian}

\section{Uji validitas}

Validitas sebuah alat ukur ditunjukkan kemampuannya mengukur apa yang seharusnya diukur. Demikian juga kuesioner riset.Kuesioner riset dikatakan valid apabila instrument tersebut benar-benar mampu mengukur besarnya nilai variabel yang diteliti. Keputusan pada sebuah butir pernyataan dapat dianggap valid jika koefisien korelasi product moment melebihi 0,30 begitupun sebaliknya jika dibawah 0,30 maka dianggap tidak valid. Pengujian validitas ini dilakukan dengan program SPSS 23.

a) Variabel integritas wajib pajak $\left(\mathrm{X}_{1}\right)$

Hasil pengujian validitas data untuk masing-masing pernyataan variabel Integritas Wajib pajak $\left(\mathrm{X}_{1}\right)$

Tabel 2. Variabel integritas

\begin{tabular}{|c|c|c|c|}
\hline $\begin{array}{c}\text { Nomor item } \\
\text { Pertanyaan }\end{array}$ & $\begin{array}{c}\text { Koefisien } \\
\text { Korelasi (r) }\end{array}$ & $\begin{array}{c}\text { Nilai Batas } \\
\text { Korelasi (r) }\end{array}$ & Keterangan \\
\hline $\mathrm{X}_{11}$ & 0,763 & 0.30 & Valid \\
\hline $\mathrm{X}_{12}$ & 0,820 & 0.30 & Valid \\
\hline $\mathrm{X}_{13}$ & 0,714 & 0.30 & Valid \\
\hline
\end{tabular}

Berdasarkan tabel diatas terlihat bahwa semua pernyataan variabel mempunyai nilai $r$-hitung di atas 0,30 sehingga dapat disimpulkan bahwa seluruh item pernyataan pada variabel pengetahuan perpajakan (X1) dinyatakan valid dan dapat diproses lebih lanjut.

b) Variabel pengetahuan dan pemahaman perpajakan $\left(\mathrm{X}_{2}\right)$

Hasil pengujian validitas data untuk masing-masing pernyataan variabel Pengetahuan dan pemahaman perpajakan $\left(\mathrm{X}_{2}\right)$.

Tabel 3. Variabel Pengatahuan dan pemahaman perpajakan

\begin{tabular}{|c|c|c|c|}
\hline $\begin{array}{c}\text { Nomor Item } \\
\text { Pertanyaan }\end{array}$ & $\begin{array}{c}\text { Koefisien } \\
\text { Korelasi (r) }\end{array}$ & $\begin{array}{c}\text { Nilai Batas } \\
\text { Korelasi (r) }\end{array}$ & Keterangan \\
\hline$X_{21}$ & 0,814 & 0,30 & Valid \\
\hline$X_{22}$ & 0,751 & 0,30 & Valid \\
\hline$X_{23}$ & 0,722 & 0,30 & Valid \\
\hline
\end{tabular}

Berdasarkan tabel diatas terlihat bahwa semua pernyataan variabel mempunyai nilai $r$-hitung di atas 0,30 sehingga dapat disimpulkan bahwa seluruh item pernyataan pada variabel pengetahuan dan pemahaman perpajakan $\left(\mathrm{X}_{2}\right)$ dinyatakan valid dan dapat diproses lebih lanjut. 
Tabel 4. Variabel kepatuhan wajib pajak orang pribadi (Y)

Hasil pengujian validitas data untuk masing-masing pernyataan variabel Kepatuhan Wajib Pajak (Y).

\begin{tabular}{|c|c|c|c|}
\hline $\begin{array}{c}\text { Nomor Item } \\
\text { Pertanyaan }\end{array}$ & $\begin{array}{c}\text { Koefisien } \\
\text { Korelasi (r) }\end{array}$ & $\begin{array}{c}\text { Nilai Batas } \\
\text { Korelasi (r) }\end{array}$ & Keterangan \\
\hline Y1.1 & 0,556 & 0,30 & Valid \\
\hline Y1.2 & 0,807 & 0,30 & Valid \\
\hline Y1.3 & 0,809 & 0,30 & Valid \\
\hline Y1.4 & 0,524 & 0,30 & Valid \\
\hline
\end{tabular}

Berdasarkan tabel diatas terlihat bahwa semua pernyataan variabel mempunyai nilai r-hitung di atas 0,30 sehingga dapat disimpulkan bahwa seluruh item pernyataan pada variabel Kepatuhan Wajib Pajak (Y) dinyatakan valid dan dapat diproses lebih lanjut.

\section{Uji reliabilitas}

Uji reliabilitas pada dasarnya adalah untuk mengetahui sejauh mana hasil suatu pengukuran yang dilakukan dapat dipercaya. Jika hasil pengukuran yang dilakukan secara berulang relatif sama maka pengukuran tersebut dianggap memiliki tingkat reliabilitas yang baik. Uji reliabilitas yang paling sering digunakan adalah uji alpha. Pada uji reliabilitas ini, peneliti menggunakan nilai cronbach's alpha. Jika nilai cronbach's alpha lebih besar dari 0,60 maka kuesioner tersebut dikatakan reliabel. Pengujian reliabel ini menggunakan SPSS.Berikut ini hasil pengujian untuk setiap item pernyataan variabel penelitian.

Tabel 5. Hasil uji reliabilitas

\begin{tabular}{|c|c|c|c|}
\hline Variabel & $\begin{array}{c}\text { Cronbach's Alpha } \\
(\boldsymbol{\alpha})\end{array}$ & $\begin{array}{c}\text { Nilai Batas Alpha } \\
(\boldsymbol{\alpha})\end{array}$ & Keterangan \\
\hline $\mathrm{X} 1$ & 0,620 & 0,60 & Reliabel \\
\hline $\mathrm{X} 2$ & 0,629 & 0,60 & Reliabel \\
\hline $\mathrm{Y}$ & 0,625 & 0,60 & Reliabel \\
\hline
\end{tabular}

Berdasarkan hasil uji reliabilitas yang tersaji pada tabel diatas, menunjukkan bahwa semua variabel yang dijadikan item dalam penelitian ini memiliki tingkat reliabilitas yang baik. Hal ini terlihat dari hasil pengujian, nilai cronbach's alpha setiap variabel diatas 0,60 sehingga dapat disimpulkan bahwa kuesioner pada setiap variabel dalam penelitian yang digunakan akan mampu memperoleh data yang konsisten sehingga semua instrumen dapat diproses lebih lanjut.

\section{Uji BLUE (Asumsi Klasik)}

Pengujian persyaratan analisis yang digunakan yaitu uji penyimpangan asumsi klasik yang bertujuan untuk memenuhi kriteria BLUE (Best, Linear, Unbiased, Estimator). Uji BLUE (Asumsi Klasik) ini terdiri dari uji normalitas, uji multikolinearitas, uji auto korelasi, dan uji heteroskedastisitas. 


\section{JURNAL AKUNTANSI DAN MANAJEMEN}

Issue 1 (Agustus, 2018)

a. Uji Normalitas

Uji normalitas bertujuan untuk menguji apakah dalam model regresi variabel memiliki distribusi normal. Uji normalitas pada penelitian ini menggunakan uji statistik non-parametik Kolmogorov-smimov. Variabel dikatakan distribusi normal jika nilai Kolmogorov-smimov memiliki tingkat signifikan lebih besar dari 0,05. Hasil uji normalitas dapat ditunjukkan pada tabel berikut:

Tabel 5. Normalitas data

\begin{tabular}{|c|c|c|}
\hline & & $\begin{array}{c}\text { Unstandardized } \\
\text { Residual } \\
\end{array}$ \\
\hline $\mathrm{N}$ & & 45 \\
\hline & Mean & .0000000 \\
\hline Normal Parameters ${ }^{\mathrm{a}, \mathrm{b}}$ & Std. Deviation & .78235158 \\
\hline & Absolute & .128 \\
\hline Most Extreme Differences & Positive & .128 \\
\hline & Negative & -.116 \\
\hline Test Statistic & & .128 \\
\hline Asymp. Sig. (2-tailed) & & $.060^{c}$ \\
\hline
\end{tabular}

a. Test distribution is Normal.

b. Calculated from data.

c. Lilliefors Significance Correction.

Berdasarkan hasil uji Kolmogorov-smirnov Test pada tabel diatas, menunjukkan nilai signifikansi (Asymp.Sig) sebesar 0.060 ini menunjukan bahwa nilai signifikansi lebih besar dari tingkat signifikansi sebesar 5\% (0.05). Jadi dapat disimpulkan bahwa data residual yang diuji terdistribusi normal dan model regresi memenuhi asumsi klasik.

b. Uji Multikolinieritas

Uji ini bertujuan menentukan dalam suatu model regresi linier berganda terdapat korelasi antara variabel. Model regresi linier berganda yang baik adalah yang tidak mengalami multikolinieritas. Salah satu cara untuk menguji multikolinieritas adalah dengan melihat nilai Tolerance dan variance inflation factor (VIF). Nilai Tolerance harus lebih besar dari 0,10, sementara untuk VIF nilainya harus lebih kecil dari 10,00. Berikut tabel untuk hasil uji multikolonieritas:

Tabel 6. Multikolinearitas data

\begin{tabular}{|ll|c|c|}
\hline \multirow{2}{*}{ Model } & \multicolumn{2}{|c|}{ Collinearity Statistics } \\
\cline { 3 - 4 } & (Constant) & Tolerance & VIF \\
& INTEGRITAS & & 1.055 \\
& PENGETAHUAN DAN & .948 & 1.055 \\
\hline & PEMAHAMAN PERPAJAKAN & .948 & \\
\hline
\end{tabular}

a. Dependent Variable: KEPATUHAN WAJIB PAJAK

Authors : Nurul Khotimah dkk. (Agustus 2018). 01 - 15 


\section{JURNAL AKUNTANSI DAN MANAJEMEN}

Issue 1 (Agustus, 2018)

Berdasarkan tabel di atas maka nilai Tolerance untuk variabel Integritas (X1) yakni 0,948 lebih besar dari 0.10 dan nilai VIF yakni 1.055 lebih kecil dari 10,00. Sementara nilai Tolerance untuk variabel pengetahuan dan pemahaman perpajakan (X2) yakni 0,948 lebih besar dari 1.055 lebih kecil dari 10,00 . Sehingga dapat disimpulkan data yang diuji tidak terjadi multikolonieritas.

c. Uji Heteroskedastisitas

Uji Heteroskedastisitas bertujuan untuk menguji apakah dalam model regresi terjadi ketidaksamaan variance dari residual satu pengamatan ke pengamatan yang lain, model regresi yang baik seharusnya tidak terjadi heteroskedastisitas. Jika nilai signifikan lebih besar dari 0,05, maka tidak terjadi heteroskedastisitas. Uji Heteroskedastisitas dilakukan dengan Uji Glejser.Berikut tabel untuk hasil uji heteroskedastisitas.

Tabel 7. Heterokedastisitas data

\begin{tabular}{|c|c|c|c|c|c|c|}
\hline & \multirow[b]{2}{*}{ Model } & \multicolumn{2}{|c|}{ Unstandardized Coefficients } & \multirow{2}{*}{$\begin{array}{c}\begin{array}{c}\text { Standardized } \\
\text { Coefficients }\end{array} \\
\text { Beta }\end{array}$} & \multirow[b]{2}{*}{$\mathrm{t}$} & \multirow[b]{2}{*}{ Sig. } \\
\hline & & $\mathrm{B}$ & Std. Error & & & \\
\hline \multirow[t]{3}{*}{1} & (Constant) & 2.793 & 1.545 & & 1.808 & .078 \\
\hline & $\mathrm{X} 1$ & .040 & .103 & .059 & .387 & .701 \\
\hline & X2 & -.205 & .110 & -.283 & -1.859 & .070 \\
\hline
\end{tabular}

a. Dependent Variable: RES2

Berdasarkan Tabel tersebut dapat diketahui bahwa nilai signifikan Variabel Integritas (X1) sebesar 0,701 lebih besar dari 0,05 dan Variabel Pengetahuan dan pemahaman perpajakan (X2) sebesar 0,070 lebih besar dari 0,05. Artinya tidak terjadi heteroskedastisitas pada Variabel Integritas (X1), dan Pegetahuan dan pemahaman perpajakan (X2) nilai di atas 0,05 memiliki asumsi heteroskedastisitas, sehingga data dapat diuji pada pengujian selanjutnya.

\section{Analisis Data Penelitan}

\section{(1) Analisis Statistik Deskriptif}

Analisis statistik deskriptif data digunakan untuk memberikan gambaran mengenai penyebaran data variabel-variabel penelitian yaitu Integritas pepajakan (X1) Pengetahuan dan Pemahaman perpajakan (X2) serta variabel Kepatuhan Wajib Pajak (Y) telah dilakukan dengan baik.

Tabel 8. Statistik deskriptif

\begin{tabular}{|c|c|c|c|c|c|}
\hline & $\mathrm{N}$ & \multicolumn{2}{|l|}{ Mean } & Std. Deviation \\
\hline & & Statistic & Statistic & Std. Error & Statistic \\
\hline INTEGRITAS PAJAK & & 45 & 11.5111 & .20194 & 1.35466 \\
\hline $\begin{array}{l}\text { PENGETAHUAN } \\
\text { PEMAHAMAN PERAIAKAN }\end{array}$ & DAN & 45 & 11.6444 & .18844 & 1.26411 \\
\hline KEPATUHAN WAJIB PAJAK & & 45 & 15.4667 & .22156 & 1.48630 \\
\hline Valid N (listwise) & & 45 & & & \\
\hline
\end{tabular}


Berdasarkan pada tersebut dapat dilihat bahwa nilai rata-rata (mean) variabel Integritas (X1) 11.5111 lebih besar dari standar deviasi 1.35466 Variabel Pengetahuan dan pemahaman perpajakan (X2) sebesar 11.6444 lebih besar dari standar deviasi 1.264111 ini menunjukkan bahwa penyebaran data instrumen masing-masing variabel X1 dan X2 adalah baik. Begitupun dengan nilai rata-rata (mean) variabel Kepatuhan Wajib pajak (Y) 11.5111 lebih besar dari standar deviasi yang berarti data yang disebar baik.

\section{(2) Analisis Regresi berganda}

Regresi linier berganda digunakan untuk mengetahui pengaruh antara variabel bebas (Integritas, pengetahuan dan pemahaman perpajakan) terhadap variabel terikat (Kepatuhan wajib pajak). Analisis ini dilakukan untuk mengetahui pengaruh variabel bebas terhadap variabel terikat. Berdasarkan hal tersebut, maka untuk mengetahui nilai persamaan regresi dipergunakan tabel berikut ini :

Tabel 9. Regersi Linear Berganda

\section{Coefficients ${ }^{\mathrm{a}}$}

\begin{tabular}{|c|c|c|c|c|c|c|}
\hline & \multirow{2}{*}{ Model } & \multicolumn{2}{|c|}{$\begin{array}{l}\text { Unstandardized } \\
\text { Coefficients }\end{array}$} & $\begin{array}{c}\text { Standardized } \\
\text { Coefficients }\end{array}$ & \multirow{2}{*}{$\mathrm{t}$} & \multirow{2}{*}{ Sig. } \\
\hline & & B & $\begin{array}{l}\text { Std. } \\
\text { Error }\end{array}$ & Beta & & \\
\hline \multirow[t]{4}{*}{1} & (Constant) & & & & & \\
\hline & & 6.765 & 2.215 & & 3.055 & .004 \\
\hline & $\mathrm{X} 1$ & .250 & .148 & .228 & 1.690 & .098 \\
\hline & X2 & .500 & .158 & .425 & 3.158 & .003 \\
\hline
\end{tabular}

a. Dependent Variable: $Y$

b0 $=6.765$ artinya jika tidak ada perubahan pada Integritas, pengetahuan dan pemahaman perpajakan sebagai variabel bebas, maka nilai kepatuhan wajib pajak 6.765 sebagai nilai konstan sebagai variabel terikat. $\mathrm{b} 1=0,250$ berarti ketika Integritas naik $1 \%$ akan mempengaruhi peningkatan kepatuhan wajib pajak orang pribadi sebesar $0,250 . b 2=0,500$ berarti ketika pengetahuan dan pemahaman perpajakan naik 1\% akan mempengaruhi kepatuhan wajib pajak orang pribadi sebesar 0,500.

\section{(3) Uji Koefisien Determinasi (Uji R²)}

Untuk mengukur seberapa jauh kemampuan model dalam menerangkan variasi variabel dependen, maka digunakanlah koefisien determinasi. Dalam penelitian ini nilai koefisien determinasi yang dipakai adalah nilai Adjusted $R$ Square. Tabel berikut ini menyajikan nilai koefisien determinasi dari model penelitian. 
Tabel 10. Koefisien Determinasi (Uji R²)

\begin{tabular}{|c|c|c|c|c|}
\hline & & & Model Summary \\
Model & $\mathrm{R}$ & R Square & $\begin{array}{c}\text { Adjusted R } \\
\text { Square }\end{array}$ & $\begin{array}{c}\text { Std. Error of } \\
\text { the Estimate }\end{array}$ \\
\hline 1 & $.526^{\mathrm{a}}$ & .277 & .243 & 129.347 \\
\hline
\end{tabular}

a. Predictors: (Constant), X2, X1

b. Dependent Variable: $Y$

Tabel di atas menunjukkan bahwa koefisien determinasi menentukan seberapa besar variabel independen dapat menjelaskan variabel dependennya. Berdasarkan tabel 4.9 dapat diketahui koefisien determinasi $\left(\mathrm{R}^{2}\right)$ dalam penelitian ini sebesar 0,277 atau 27,7\%, yang berarti kepatuhan wajib pajak sebesar $27,7 \%$ sedangkan sisanya sebesar 72,3\% dijelaskan oleh faktor lain yang tidak dilakukan dalam penelitian ini.

\section{(4) Uji t-test}

Selanjutnya untuk mengetahui koefisien regresi variabel bebas mana yang pengaruhnya signifikan maka dilakukan uji koefisien regresi secara individual (parsial). Perhitungan koefisien regresi secara parsial dapat dilihat :

Tabel 11. t-test

Coefficients $^{\mathrm{a}}$

\begin{tabular}{|c|c|c|c|c|c|c|}
\hline & \multirow{2}{*}{ Model } & \multicolumn{2}{|c|}{$\begin{array}{l}\text { Unstandardized } \\
\text { Coefficients }\end{array}$} & \multirow{2}{*}{$\begin{array}{c}\begin{array}{c}\text { Standardized } \\
\text { Coefficients }\end{array} \\
\text { Beta } \\
\end{array}$} & \multirow{2}{*}{$\mathrm{t}$} & \multirow{2}{*}{ Sig. } \\
\hline & & B & Std. Error & & & \\
\hline \multirow[t]{4}{*}{1} & (Constant) & & & & & \\
\hline & & 6.765 & 2.215 & & 3.055 & .004 \\
\hline & $\mathrm{X} 1$ & .250 & .148 & .228 & 1.690 & .098 \\
\hline & $\mathrm{X} 2$ & .500 & .158 & .425 & 3.158 & .003 \\
\hline
\end{tabular}

a. Dependent Variable: Y

Uji t pada dasarnya menunjukkan seberapa jauh pengaruh satu variabel bebas (independent) secara parsial atau individual dalam mempengaruhi variabel tidak bebas.

\section{a) Pengaruh Integritas Terhadap Kepatuhan Wajib Pajak}

Berdasarkan hasil perhitungan koofisien regresi secara parsial yang dilihat pada tabel khususnya tabel 11. coeficient diperoleh nilai $t_{\text {hit }}$ variabel Integritas 1.690 dan tidak signifikan pada tingkat kepercayaan $(\alpha=0.05)$, nilai siginifkan yang diperoleh sebesar 0.098 lebih besar dari $0.05(0.098>0.05)$. nilai $t_{\text {tab }} 1,354$ dengan $\alpha=0.05$ dan derajat bebas $=45$ $-1-1=43$ maka diperoleh nilai $t_{\text {tab }} 1,354$. Oleh karena itu nilai $t_{\text {hit }}$ untuk 
koefisien variabel Integritas sebesar 1.690 lebih besar dari tab sebesar 1,354 (1.690>1.354) maka hipotesis diterima. Artinya peran Integritas berpengaruh positif tidak signifikan terhadap kepatuhan wajib pajak orang pribadi.

\section{b) Pengaruh Pengetahuan dan pemahaman perpajakan terhadap Kepatuhan Wajib Pajak.}

Berdasarkan hasil perhitungan koofisien regresi secara parsial yang dilihat pada tabel khususnya tabel 4.18 coofisient diperoleh nilai $t_{\text {hit }}$ variabel pengetahuan dan pemahaman perpajakan 3.654 dan signifikan pada tingkat kepercayaan $(\alpha=0.05)$, nilai siginifkan yang diperoleh sebesar 0.003 lebih kecil dari $0.05(0.003<0.05)$. nilai tabdengan $\alpha=0.05$ dan derajat bebas $=45-1-1=43$ maka diperoleh nilai $t_{\text {tab }} 1,264$. Oleh karena itu nilai $t_{\text {hit }}$ untuk koefisien variabel pengetahuan dan pemahaman perpajakan sebesar 3.654 lebih besar dari tab sebesar 1.264 (3.654 > 1.264) maka hipotesis diterima. Artinya peran Pengetahuan dan pemahaman perpajakan berpengaruh positif dan signifikan terhadap kepatuhan wajib pajak orang pribadi.

(5) Interpretasi Hasil Penelitian

\section{a) Pengaruh Integritas Terhadap Kepatuhan Wajib Pajak}

Hasil pengujian hipotesis untuk variabel Integritas (X1) terhadap kepatuhan wajib pajak menunjukkan bahwa Integritas berpengaruh positif tapi tidak signifikan terhadap kepatuhan wajib pajak. Hasil uji t diperoleh arah positif $\quad 0,098$ dan nilai $t$ hitung 1.690 dengan nilai signifikan 0.098. Hal ini menunjukkan bahwa nilai signifikansi lebih besar dari taraf signifikansi 5\% $(0.098>0.05)$ dan nilai $t_{\text {hitung }}$ lebih besar dari nilai $t_{\text {tabel }}(1.690>1.354)$.

Hasil penelitian ini sejalan dengan hasil penelitian yang dilakukan oleh Wisnu (2016) yang menunjukkan bahwa Integritas perpajakan tidak berpengaruh signifikan terhadap kepatuhan wajib pajak. Artinya integritas yang dimiliki oleh wajib pajak tidak dapat meningkatkan kepatuhan Wajib Pajak Orang Pribadi (WPOP). Karena seringkali Integritas dikaitkan dengan kejujuran wajib pajak, dalam hal pelaporan dan pembayaran pajak tingkat kejujuran yang dimiliki oleh wajib pajak masih sangat minim.

\section{b) Pengaruh Pengetahuan dan Pemahaman Perpajakan Terhadap Kepatuhan Wajib Pajak.}

Hasil pengujian hipotesis untuk Pengetahuan dan pemahaman Perpajakan (X2) terhadap kepatuhan wajib pajak orang pribadi menunjukkan bahwa pengetahuan dan pemahaman perpajakan berpengaruh positif dan signifikan terhadap kepatuhan wajib pajaki. Hasil uji t diperoleh arah positif sebesar 0,003 dan nilai t hitung 3.158 dengan nilai signifikan 0.003. Hal ini menunjukkan bahwa nilai signifikansi lebih kecil dari taraf signifikansi $5 \%(0.003<0.05)$ dan nilai $t$ hitung lebih besar dari nilai t tabel $(3.158>1.264)$.

Halaman 12

Authors : Nurul Khotimah dkk. (Agustus 2018). 01 - 15 


\section{JURNAL AKUNTANSI DAN MANAJEMEN}

Issue 1 (Agustus, 2018)

Hasil penelitian ini sejalan dengan hasil penelitian yang dilakukan oleh Setiawan (2013) yang menunjukkan bahwa pengetahuan dan pemahaman perpajakan berpengaruh signifikan terhadap kepatuhan wajib pajak. Artinya pengetahuan dan pemahaman perpajakan dapat meningkatkan kepatuhan wajib pajak. Semakin baik pengetahuan dan pemahaman perpajakan yang dimiliki oleh wajib pajak maka kepatuhan wajib pajak pada KPP Pratama Makassar Utara semakin meningkat.

\section{KESIMPULAN}

Penelitian ini bertujuan untuk menguji pengaruh Integritas, Pengetahuan dan Pemahaman Perpajakan terhadap Kepatuhan Wajib Pajak pada Kantor Pelayanan Pajak Pratama (KPP) Makassar Utara.

Berdasarlkan hasil penelitian yang telah diuraikan sebelumnya maka dapat ditarik kesimpulan sebagai berikut :

1. Integritas tidak berpengaruh terhadap kepatuhan wajib pajak.

2. Pengetahuan dan pemahaman perpajakan berpengaruh positif dan signifikan terhadap kepatuhan wajib pajak.

\section{DAFTAR PUSTAKA}

Andriana, Ateng. (2011). Analisis Atas Pengaruh Penerapan Self Assesment System dan Kualitas Pelayanan Pajak Terhadap Kepatuhan Format Wajib Pajak di KPP Cicadas Kota Bandung. Skripsi Unikom. Bandung.

Anggraeni, Intan Yuningtyas. (2013). Faktor-Faktor Yang Mempengaruhi Kepatuhan Wajib Pajak Terhadap Penerimaan Pajak Penghasilan Pada Kantor Pelayanan Pajak Pratama Semarang Tengah Satu. Universitas Diponegoro Journal of Social and Politic.

Bahar, A., \& Sjahruddin, H. (2017). Pengaruh Kualitas Produk Dan Kualitas Pelayanan Terhadap Kepuasan Konsumen Dan Minat Beli Ulang.

Chau, Gerald and Patrick Leung. (2012). A Critical Review of Fishcer Tax Compliance Model (A Research Syntesis). Journal of Accounting and Taxation.

Chau, Liung. (2013). A Critical Riview of Fischer Tax Compliance Model (A Research sysntesis). Journal of Accounting and Taxation.

Choong, K.F., \& Lai, M.L. (2009). Self Assessment Tax System and Compliance Complexities : Tax Practitioners Perspectives. Oxford Bussiness \& Economics Coference Program.

Cooper (1999). Dalam menguji tingkat keberartian pengaruh antar variabel independen dengan variabel dependen. Jurnal bisnis dan ekonomi.

Fahmi, R. Z., Sjahruddin, H., Astuti, N. P., \& Syakhrun, A. M. (2017). Pengaruh Kecukupan Modal Dan Penyaluran Kredit Terhadap Profitabilitas Perbankan.

Ghozali, Imam. (2011) . Aplikasi Analisis Multi Variate Dengan Program SPSS.Semarang : Badan Penerbitan Universitas Diponogoro.

Gunadi. (2005). Akuntansi Pajak. Jakarta : PT. Gramedia Widiasarana.

Hardiningsih, Yulianawati. (2011). Faktor-Faktor Yang Mempengaruhi Kemauan Membayar Pajak. Jurnal Dinamika Keuangan dan Perbankan. 
Herryanto,(2013). system self assessment, jurnal penelitian akuntansi pajak Universitas Udayana.

Ho, (2011). Upaya Penegakan Kepatuhan Pajak Secara Keseluruhan. E-journal UNY.

Insadha.,(2012) Indikator Integritas kepatuhan pajak terhadap kepatuhan wajib pajak. Jurnal penelitian akuntansi pajak.

Liana, Lie. (2010). Penggunaan MRA dengan SPSS untuk Menguji Pengaruh Variabel

Moderatoring terhadap Hubungan antara Variabel Independen dan Variabel Dependen. Jurnal Teknologi Informasi DINAMIK, 14,(2),90-97

Nugroho, Rahman Adi. (2012) . Faktor-Faktor yang Mempengaruhi Kemauan Untuk Membayar Pajak dengan Kesadaran Membayar Pajak Sebagai Variabel Intervening (Studi Kasus Wajib Pajak Orang Pribadi yang Melakukan Pekerjaan Bebas yang Terdaftar di KPP Pratama Semarang Tengah Satu). Skripsi Universitas Diponegoro. Semarang.

Nurmantu, S. (2011). Dasar-dasar Perpajakan. Jakarta. Ind-Hil-Co.

Palil. (2015) . Surat Pemberitahuan (SPT), pembayaran, tempat pembayaran, denda dan batas waktu pembayaran atau pelaporan SPT.

Prasetyo. (2011). Teori Pengetahuan www.dpr.go.id (tanggal akses: 5 Maret 2018

Purwoko, Aditya Dwi. (2012). Pengaruh Pelaksanaan Self Assessment System, Kualitas Pelayanan KPP, Tingkat Pendidikan Terhadap Motivasi Wajib Pajak Memenuhi Kewajiban Pajak. Skripsi UIN. Jakarta.

Putri, Siswanto, Jati, I Ketut. (2013). Faktor-Faktor yang Mempengaruhi Kepatuhan Wajib Pajak dalam Membayar Pajak Kendaraan Bermotor di Denpasar. skripsi dan batas waktu pembayaran atau pelaporan SPT.

Qomaria, Siti. (2013) .Analisis Pengaruh Pengetahuan Tentang Pajak dan Tingkat Pendidikan Wajib Pajak Terhadap Kesadaran Membayar Pajak. Skripsi UIN. Jakarta.

Rahayu, P. (2010) Indikator Pengetahuan dan Pemahaman Perpajakan dan kepatuhan wajib pajak. Jurnal penelitian akuntansi pajak UNY.

Resmi, Siti. (2017). Perpajakan : Teori dan Kasus. Edisi 6.Jakarta : Salemba Empat.

Rustyaningsih. (2011). Faktor-faktor yang mempengaruhi kepatuhan wajib pajak. Skripsi UIN Jakarta.

Setiawan., (2016). Pengaruh kesadaran pengetahuan dan pemahaman perpajakan terhadap kepatuhan wajib pajak. E-Journal Akuntansi Universitas Udayana.

Simposium, (2016). Teori Integritas. www.dpr.go.id (tanggal akses: 5 Maret 2018.)

Sri Rustyaningsih.,(2011). Kepatuhan dan kesadaran pemenuhan kewajiban perpajakan tercermin dalam situasi. Tentang Ketentuan Umum dan Tata Cara Perpajakan. Melalui : www.dpr.go.id (tanggal akses : 5 Maret 2018.

Sugiyono. (2014). Metode Penelitian Bisnis. Bandung: Alfabeta.

Sulistyo.,(2010). Prespektif dasar kepatuhan pada hukum. E-Jurnal akuntansi pajak Universitas Surabaya.

Sunarto, (2013). Integritas Pajak sebagai Pemoderasi Pengaruh Sanksi Pajak dan Kesadaran Pada Kepatuhan Wajib Pajak Orang Pribadi. Skripsi. Fakultas Ekonomi dan Bisnis Universitas Udayana.

Sjahruddin, H. (2018). Persepsi Mahasiswa Strata Satu Akuntansi Terhadap Pendidikan Profesi Akuntansi (PPAk)(Studi Pada Universitas Hasanuddin Makassar). 


\section{JURNAL AKUNTANSI DAN MANAJEMEN}

Issue 1 (Agustus, 2018)

Undang-Undang Ketentuan Umum dan Tata cara perpajakan (KUP) dan Peraturan Pelaksanaannya. 2013. Kementerian Keuangan Republik Indonesia Direktorat Jendral Pajak. Jakarta.

Undang-Undang Republik Indonesia Nomor 28 Tahun 2007. Tentang Ketentuan Umum dan Tata Cara Perpajakan. Jakarta: Penerbit Buku Berita Pajak.

Widayanti, Nurlis. (2010) hubungan pengetahuan dan pemahaman terhadap kepatuhan wajib pajak. Skripsi UNPAD.

Wisnu. (2016). Pengaruh Integritas Terhadap Kepatuhan Wajib Pajak. Jurnal umum Akuntansi Perpajakan. 